\title{
MedienPädagogik
}

Zeitschrift für Theorie und Praxis der Medienbildung

\section{Social Bots and Fake News as (not) seen from the Viewpoint of Digital Education Frameworks}

Dietmar Janetzko

\begin{abstract}
Over recent years, international organisations like the EU and UNESCO have set up a number of proposals, models and frameworks that seek (i) to map and to conceptualize digital literacy and related concepts, e.g. information, digital or media literacy, digital competence, digital skills and (ii) to formulate policies and recommendations based on the conceptualizations developed. The resulting frameworks, such as Digital Competence (DigComp) developed by the EU, or Media and Information Literacy (MIL) developed by UNESCO, have a strong formative power on a global scale. Affected are policies, laws, regulations, research activities, and academic disciplines like media pedagogy and mindsets. Do these frameworks consider the effects of disruptive attempts by digital media to intervene in public debates e. g. social bots, fake news and other manifestations of biased or false information online? Do they offer avenues for reflection and action to address them? Guided by these questions, this paper studies the flagship frameworks on digital education of the EU and UNESCO, DigComp and MIL. It finds biases in both frameworks. To different degrees, both tend to overemphasize the practical and instrumental use of digital literacy.
\end{abstract}

Social Bots und Fake News - Was EU- und UNESCO-Referenzrahmen zum Lernen im digitalen Zeitalter darüber (nicht) sagen

\begin{abstract}
Zusammenfassung
In den letzten Jahren haben internationale Organisationen wie die EU und die UNESCO eine Reihe von Vorschlägen und Strategiepapieren zur Bildung und Ausbildung im Zusammenhang mit digitalen Medien entwickelt. Mit den dabei entstandenen Rahmenkonzepten der EU (Digital Competence, DigComp) sowie der UNESCO (Media and Information Literacy, MIL) werden im Kern zwei zusammenhängende Ziele verfolgt: (i) digitale Bildung bzw. digitale Kompetenzen, Fähigkeiten und zugehörige Einstellungen umfassend zu kartographieren sowie (ii) über die dabei konzipierten edukativ-politischen Rahmenkonzepte Projektförderungen, Bildungs- bzw. Ausbildungsinitiativen sowie Gesetzesvorlagen anzustossen. Tatsächlich sind DigComp und MIL bereits dabei, auf internationaler Ebene einen prägenden Einfluss zu nahezu allen Fragen der Bildung und Ausbildung im Bereich digitaler Medien auszuüben. Beide Initiativen haben innerhalb der genannten Organisa-
\end{abstract}


tionen Leuchtturmcharakter, werden bislang aber von der allgemeinen Öffentlichkeit und der medienpädagogischen Fachöffentlichkeit kaum wahrgenommen. Dessen ungeachtet verbindet sich mit DigComp und MIL jeweils ein impliziter Anspruch auf einen - im Bedarfsfall zu aktualisierenden - Gesamtentwurf zur Analyse und Gestaltung medienpädagogischer Bildung und Ausbildung. Dies gilt für Gesetzesvorlagen, Regulierungen, Forschungsaktivitäten. Sind diese Rahmenkonzepte anschlussfähig an medienpädagogische Debatten über disruptive Versuche, in via soziale Medien geführte öffentliche Debatten einzugreifen, die sich über social bots, fake news oder andere Formen der Einflussnahme manifestieren? Erschliessen sie dazu Reflexionsräume und Handlungsoptionen? Geleitet von diesen Fragen betrachtet der vorliegende Aufsatz, die Rahmenkonzepte der EU und UNESCO, DigComp and MIL. Dabei zeigt sich, dass beide Rahmenkonzepte von Schieflagen gekennzeichnet sind. DigComp und MIL überbetonen die instrumentelle, auf Verwertung am Arbeitsmarkt bezogene Sicht auf digitale Medien - allerdings ist diese Gewichtung bei DigComp stärker ausgeprägt als bei MIL. Obgleich emphatische Appelle zu einem kritischen und reflektierten Umgang mit digitalen Medien weder bei DigComp noch MIL fehlen, bleibt die Ausgestaltung in dieser Hinsicht blass und hat bislang kaum konkretisierende Folgeaktivitäten nach sich gezogen. Bei allen Gesamtentwurfsansprüchen verkennen sowohl MIL und noch stärker DigComp die Rolle sozialer Medien bei der Ermöglichung eines öffentlichen Diskurses sowie ihres Zusammenhanges mit medienpädagogischen Fragen.

\section{Introduction}

Modern societies rely to a considerable degree on public communication. Disruption of communication in the public sphere, e. g. in social media, can be precarious and is likely to trigger resonance in one or several function systems of society and to manifest itself again via communication. It is against this background that disruptive attempts of digital media to intervene in public debates e. g. social bots, fake news and other manifestations of strategic and possibly IT-supported deployment of false or twisted information online, currently receive a lot of attention (e.g. Connolly 2016). An indication of the importance of these disruptive attempts to the inner working of communication-based societies is that they have spawned intensive discussions in several function systems, particularly in politics (Woolley 2016; Delvaux 2017), science (Morris et al. 2012; Ferrara et al. 2014) and law (Dankert and Dreyer 2017). Digital literacy has repeatedly been conjured up to remedy this situation. As yet, however, the education system appears resoundingly silent vis-à-vis the strategic deployment of false or twisted information in digital media, e. g. via social bots. At the time of writing this article, this is true where academic publications are concerned. ${ }^{1}$ The motivation behind the work outlined in this paper has been sparked by the sharp contrast between the silence of the academic literature and the call for an

1 In the educational blogosphere, a few contributions discuss fake news and social bots (e. g. Seargeant and Tagg 2016). 
increased engagement in media literacy in public debates on social bots and related themes like fake news (Chaffee 2016). The goal of the paper is to answer the question whether and to what degree current frameworks of digital competence or literacy, introduced by the EU and UNESCO, cater for systematic manipulation of public debates in social media via, e. g. social bots.

Starting with observations and reflections of Richard A. Lanham (1995) and Paul Gilster (1996), two educators, though not educational researchers ${ }^{2}$, the trajectory of digital literacy involved a string of reconceptualizations until two concepts of education in the digital ages - digital competence and multimedia and information literacy - became central to organisations like the EU and UNESCO. Both organisations developed comprehensive digital frameworks or models that attempt to map abilities, knowledge and attitudes involved. Embraced by the aforementioned international organisations, digital competence or literacy is much more than a research area. It has become an integral part of the social and political agenda in many countries.

This paper is organized as follows. Firstly, it sketches the quest for a concept of education in the digital age over the last 30 years. Secondly, a more in-depth comparison between the digital education frameworks of EU and UNESCO is offered. Thirdly, the paper compares and contrasts the notions of digital education of the EU and UNECSO with a notion of digital literacy that draws its inspirations from New Literacy Studies and Critical Media Literacy in light of disruptive deployments of social media.

\section{From Digital Literacy to Digital Literacies}

Paul Gilster is credited with being one of the first to familiarize a wider audience with the idea that when society is increasingly determined by online technologies, traditional notions like knowledge, abilities or skills and attitudes towards them, are bound to change (Gilster 1997): In his book Digital Literacy he wrote

Digital literacy is the ability to understand and use information in multiple formats from a wide range of sources when it is presented via computers (Gilster, 1997, 1).

By the time Gilster published his book, the Internet was no longer only a hobby horse of nerds, but on its way to becoming an essential part of daily life and of society in general. Gilster was well aware of the enormous impact that digital media was likely to have, and accordingly he was cognizant of their chances and risks.

Acquiring digital literacy for Internet use involves mastering a set of core competencies. The most essential of these is the ability to make informed judgments about what you find on-line, for unlike conventional media, much of the Net is unfiltered by editors and open to the contributions of all (Gilster 1997, 1f).

2 At the time of writing the work referenced above, Richard A. Lanham was a professor emeritus of English at the University of California, Los Angeles and president of Rhetorica, Inc., a media production company. Paul Gilster was a scholar and teacher in medieval English and history. 
Together with the even earlier publication of (Lanham 1995), who emphasized abilities required to decipher multimediated information, Gilster's book marks the pioneering stage in work on digital literacy and related concepts. In this stage, the dual nature of digital literacy became obvious. On the one hand, it provided a conceptual roof for education in the digital age and miscellaneous challenges of cultural, social and political participation. On the other, education in the digital age was an unmarked space that stimulated a Cambrian explosion in the field, i. e. a large diversity of often explorative conceptualization of digital literacy. Many competing definitions were advanced, but no conceptualization of digital literacy had achieved dominance.

Early on, discussions in the field were drawn to the distinction between technical and other abilities, like cultural, social or psychological abilities. During this time, digital literacy was recognized to be a multifaceted concept that should better be used in plural. In fact, on browsing the literature on digital literacy over the following years (e. g. Kan 2008; Bawden 2008) one is struck by the multitude of aspects different authors attributed to digital literacy. Many of them postulated lists of various types of more basic literacies, e. g. photo-visual literacy, reproduction literacy, branching literacy, information literacy or socio-emotional literacy (Eshet-Alkalai 2004; Stordy 2015). Some authors (e.g. Bawden 2008) even celebrated the diversity of different literacies subsumed under the rubric of digital literacy. Multiple literacies are taken into account because of the multitude of manifestations of digital media, their many roles in daily life and the diversity of theories in this field. The latter includes the critical tradition of New Literacy Studies, which

takes nothing for granted with respect to literacy and the social practices with which it became associated, problematising what counts as literacy at any time and place and asking «whose literacies» are dominant and whose are marginalized or resistant (Street 2003, 71).

Initially motivated by a critique of more traditional literacy studies, later work of New Literacy Studies took a digital turn and critically examined educational agendas inspired by digital media or other aspects of media in the digital age (e. g. Mills 2010). Overall, however, New Literacy Studies remains a minority position, even though some of the concerns raised, e. g. digital divide, are also addressed in work outside this field of studies.

Clearly, the discussion of digital literacy influenced ideas of education on the individual level with regard to the canon of teaching and learning content and the methods involved. This debate and its ramifications continues to impact on the level of the disciplinary setup in academia and beyond. Firstly, in the academic space, digital literacy and related concepts have gained attention, particularly in the humanities (e.g. Schwarz 2003), which traditionally study processes of sense-making. Secondly, it is associated with the introduction of new sub-disciplines or new degree courses like, e.g. digital humanities, e-learning or technology enhanced learning. 
Thirdly, there was never a strong disciplinary imprint of digital literacy. In other words, no particular academic discipline conceived of it as a discrete entity, in their own way and differing from the conceptions of others. But although discussions on digital literacy have prompted reflections on interdisciplinarity (Søby 2015), there are some disciplinary preferences in the adoption of themes associated with digital literacy. For instance, processing information provided via digital media has become a topic of psychology; themes like digital dividend or digital divide tend to be topics of sociology or political science; verifying the credibility of sources is a topic likely to be found in journalism and pedagogy. Fourthly, going beyond academia it is worth mentioning that the debate on digital literacy is associated with an enormous boost of informal learning arrangements. Many of these have sprung up on the Internet to offer opportunities for looking-up concepts, troubleshooting in case of problems and discussing open questions.

The ramifications of digital literacy are huge. Unsurprisingly, to a number of authors, its theoretical and empirical status was unclear, and many felt the need for an integrative conceptual frame of reference (e.g. Eshet-Alkalai 2004, 103). The further development of the field, saw mainly three kinds of responses to the proliferation of theoretical concepts surrounding digital literacy: To classify digital literacies Stordy (2015) suggests that meta-skills are required to integrate the many literacies or to give up the concept of literacies and instead work towards frameworks of competencies and/or literacies The latter avenue was taken by supranational and international organizations, in particular by the EU and UNESCO, both recognizing the importance of fostering digital competencies and literacies during the first decade of the millennium.

Social Bots and Fake News as a Challenge for Learning in Digital Age

Since the nineties when the need for digital literacy was first recognized, the media exposure has increased and the nature of digital media has changed. Taken with a grain of salt, the digital media in the nineties could be compared to books that required some special reading and writing skills. But roughly at the end of the last millennium, digital media extended their functionality and became a means of communication. Social media and the Web 2.0 in general, liberated communication. But a side-effect of this development is that now public debates are threatened in many ways particularly by fabricated news. While these and other forms of manipulation are not new, they are now propelled by possibly influential digital media. This development strikes at the heart of democratic societies in the western world, which rely on communication in regards to democratic processes, particularly general elections and political debates. It is against this background that social bots and other forms and manifestations of disruptive communications, like fake news (Cooke 2017), have 
to be understood. Social bots have come to epitomize this development. They are computer systems on social media like Twitter, Facebook or Instagram, which pretend to be human and engage in persuasive communication. Entirely controlled by software, social bots can be used in large numbers to spread any message at any time. Social bots have provoked strong reactions in the political arena (e. g. Bessi and Ferrara 2016) just because of their potential to undermine public communication and possibly the very fabric of democracy itself in the western world. There are different ways to conceive of this problem from a pedagogical vantage point, with critical media literacy being one of the most obvious (Kellner-Share 2007a, b). Education can be seen not only through the lens of the labour market but also as a encouragement to «critically analyse relationships between media and audiences, information and power» (Kellner-Share 2007b, 1). This would be a meaningful starting point towards a pedagogical approach that raises the awareness and competences vis à vis disruptive forms of communication.

\section{Digital Frameworks}

Ever since the term digital literacy has been coined in the eighties, many similar terms like digital literacies, digital competence, media literacy, or e-competence were proposed as super-ordinate terms meant to subsume more specific skills and competencies, e.g. managing a digital identity. As discussed in the previous paragraph, at some point there was the need to organize these concepts, e. g. by specifying skills, knowledge and attitudes involved, finding valid indicators, providing examples, clustering them and clarifying relationships between them. Systems of concepts referring to digital competence along with more specific skills and competencies, indicators and associated examples are usually called digital framework or digital models. Frameworks may claim psychological reality, in which case they resemble a nomothetic network or a measurement model. But digital frameworks may also be put together just because other practitioners or experts recommend it. Clearly, the unsatisfying proliferation of theoretical concepts mentioned above, did not simply disappear when frameworks were deployed to come to terms with digital competence or literacies. For instance, no consensus has been achieved on the similarities or differences between either the super-ordinate terms or the specific skills, competencies and indicators. Despite these problems, the more practical need to guide policy makers and educators led to various frameworks or models of digital literacy, which

usually aim at describing, promoting and/or measuring the digital skills and underlying competencies that are needed to become digitally skilled. (Iordache et al. 2016, 4) 
Typically borne out of practical necessities, a number of quite different digital education frameworks or models were introduced in the first decade of the new millennium (e. g. Eshet-Alkalai 2004). Digital models have been developed by researchers, professional bodies and regional, national or international organisations. The following paragraphs consider only the digital frameworks developed by the EU and UNESCO. The reason for this focus is that these frameworks are known to have a strong formative power. This is true with regard to the mediatization they react to, but which they are likely to further increase, with reference to other digital frameworks and considering specific national implementations. For instance, several countries of the EU, e. g. UK, Italy, have already integrated the DigComp framework in different policy areas or they are about to do so. The situation of the digital education framework of the UNESCO is similar with MIL policies and strategies being developed and implemented across the world.

\section{EU - European Union}

The articles 126 and 127 of the treaty on European Union, as signed in Maastricht on 7 February 1992, gave the European Commission for the first time some authority in educational affairs. Article 126 speaks of «quality of education by encouraging cooperation between Member States», e. g. via language learning or youth exchange activities, and Article 127 emphasizes vocational training. Starting from the narrowly defined educational fields laid out in Article 126 and 127 of the treaty on European Union, the European Union has gradually extended their engagement in education while at the same time underscoring its role for the job market and for the competitiveness of the economy.

One of the central issues this White Paper seeks to answer, is how best to use education and training to commit European countries to a process of job creation, whilst taking control of the internationalization of the economy and the arrival of new technologies skilled. (Commission of the European Communities, 1995, 13) The Lisbon European Council (23-24 March 2000) called upon the European council and commission to develop a European framework of new basic skills to be provided through lifelong learning as a key measure in Europe's response to globalization and the shift to knowledge-based economies.

Work of the European Union with a focus on education in the digital age, gained momentum at the end of the first decade of the new millennium. At that time, several national governments, e. g. in UK, New Zealand and Australia, but also regional governments, e. g. Emilia Romagna (RER) in Northern Italy, had already recognized the importance of digital education for the economic development, participation and social inclusion. The first preliminary work on digital frameworks had already been introduced, but none had become part of national or international agendas and was 
supported accordingly. Since 2006, this began to change in the wake of a European Reference Framework of competences that responded to one of the requests articulated at the Lisbon European Council (2000). The 2006 Framework of Key Competences for Lifelong Learning consists of 8 key competences on lifelong learning with digital competence being one of them (European Parliament and the Council 2006, see below).

Apart from individual research projects, there are two strands of major digital education frameworks which were initiated at the request of the European Commission (cf. Telecentre Europe 2014).

- e-Competence Framework for ICT Users (e-CF)

- Digital Competence Framework (DIGCOMP)

\section{e-Competence Framework for ICT Users (e-CF)}

The e-Competence Framework for ICT Users (e-CF) was inspired by the European e-Skills summit 2002 in Copenhagen, which placed ICT and e-business skills and knowledge high on the agenda to drive productivity and competitiveness. This led to the establishment of an e-Competence Framework for ICT Users, as a multi-annual programme. Its overall objective was the development of an e-competence framework for ICT professionals in close liaison with stakeholders from industry, academia and administration. The framework provides a reference of 40 competencies as required and applied at the Information and Communication Technology (ICT) workplace across all industry sectors, using a common language for competencies, skills and capability levels. Since 2016, the e-Competence Framework 3.0 is a European norm (EN 16234-1, European Committee for Standardization 2014).

\section{DIGCOMP}

DIGCOMP (2012-2013) and its follow-up projects aim at a comprehensive digital framework for citizens. It originated in an EU reference framework on lifelong learning that was based on 8 key competencies with digital literacy being one of them (European Parliament and the Council 2006):

Competencies are defined here as a combination of knowledge, skills and attitudes appropriate to the context. Key competencies are those which all individuals need for personal fulfilment and development, active citizenship, social inclusion and employment ... Digital competence involves the confident and critical use of Information Society Technology (IST) for work, leisure and communication. It is underpinned by basic skills in ICT: the use of computers to retrieve, assess, store, produce, present and exchange information, and to communicate and participate in collaborative networks via the Internet. 
This communication framed and positioned digital competence in a manner that was echoed by all following publications of the EU on this subject: Firstly, digital competence is embedded into a framework of other competencies. Secondly, a nutshell definition of digital competence is provided. There is no hint given whether or not this definition is deduced from research findings. While previous work in this area oscillated between descriptive-analytical and normative positions, much of the work that followed this reference framework in the EU was purely normative and administrative. For this reason, the creation of a framework of competences can be seen as a strategy to establish 'soft policies' (Hozja, 2006). The definition provided by this communication was picked up and extended over the following years in a number of projects or project proposals, launched to develop or to support digital competence frameworks.

- Framework for developing and understanding digital competence in Europe (DIGCOMP)

- Digital Competence Framework for Citizens (DigComp 2.0)

- European entrepreneurship competence framework (EntreComp)

- Digital Competence Framework for Consumers (DigCompConsumers)

- Digital Competence Framework for Teachers (DigCompTeach)

- European Framework for Digitally Competent Educational Organisations (DigCompOrg)

While e-CF is targeting ICT professionals, the overall objective of the flagship projects of this strand (DIGCOMP/DigComp 1, DigComp 2, DigComp 2.1) is the establishment of a competence framework for citizens. The structure of DIGCOMP was taken and elaborated from the e-CF framework (Ferrari 13, 8f). Maintained and managed by different bodies of the $\mathrm{EU}^{3}$, there is a loose conceptual relationship between the DIGCOMP development projects (DIGCOMP, DigComp 2.0,DigComp 2.1) and the DIGCOMP adoption projects, e. g. EntreComp , on the one hand and the e-CF projects on the other. The following discussion considers only DIGCOMP and its successor projects as the resulting digital framework provides the «conceptual DNA», which after purpose-dependent adaption is passed on to several other digital frameworks of the EU - except those of the e-CF strand of EU projects.

DIGCOMP/DigComp 1. The development of the DIGCOMP framework was based on a review of 15 existing frameworks ranging from school curricula, implementation initiatives, certification schemes and academic papers (Ferrari 2012, 1). Moreover, it has been informed by various data collection activities including literature reviews, case study analyses, online surveys and expert interviews. The DIGCOMP framework itself (later called DigComp 1.0) is a hierarchically organized model. It specifies digital

3 The DIGCOMP projects are maintained by the Joint Research Centre (JCR) of the EU. By contrast, e-CF is managed by the European Committee for Standardization. 
competence on five dimensions (levels), which includes a self-assessment grid (Ferrari 2013). Dimension 1 consists of the 5 competence areas information, communication, content creation, safety, problem-solving. Dimension 2 further details each of the competence areas into 3-5 competencies and descriptions. For instance, the first competence area information breaks down into browsing, searching and filtering information, evaluating information, storing and retrieving information (Ferrari 2013, 5f). Since DigComp 2.0 the competence areas (dimension 1) and the individual competencies (dimension 2) often referred to as the reference model of DIGCOMP/DigComp. Dimension 3 defines proficiency levels. Describing each of the 5 competence areas via 3 proficiency levels ( - Foundation, B - Intermediate, C - Advanced), leads to a self-assessment grid. Its design is loosely based on the descriptors of the EQF (European Qualification Framework). Dimension 4 operationalises each competence area by providing specific examples of knowledge, skills, and attitudes related to the competence area in focus. Similar to dimension 3, dimension 5 makes use of three proficiency levels, but looks into the purpose or context where a competence can be applied.

DigComp 2.0. DigComp 2.0 (Vuorikari et al. 2016) works towards an update of the competence framework of DIGCOMP (2012-2013). The update was motivated by the need to integrate feedback from several bodies of the EU and by the fast-moving development of digital technologies, which in several instances necessitated a revision of concepts. The authors of DigComp 2.0 announced that DigComp will be updated every 2-4 years. The first update is scheduled to proceed in two phases. In phase 1 , the competence areas and individual competencies, i.e., the reference model, has been updated. This phase was completed in 2016 (Vuorikari et al. 2016).

DigComp 2.1. Phase 2 of the update of DigComp (Carretero et al 2017) has established more fine-grained proficiency levels and provided examples of how they are used. This work builds upon and extends the 3 proficiency levels introduced in DigComp 1 for each competence (Foundation, Intermediate Advanced), which have been replaced by an assessment grid with 8 proficient levels (using action verbs, following Bloom's taxonomy). The joint research centre (JRC) of the EU will continue to monitor the development of the DigComp framework itself, national or regional implementation initiatives and its integration with other projects or instruments of the EU.

Overall, even though DigComp claims be a digital competence framework for citizens, it conceives of competencies mainly from the viewpoint of employability. Clearly, job-related issues are essential for citizens, but reflective and critical citizens are essential as well. This aspect is indeed mentioned ${ }^{4}$, but it is not pedagogically or programmatically elaborated. This is evidenced by a close reading of Chapter 5 Use and Uptake of DigComp in one of the latest technical report of DigComp (Vuorikari

4 In DigComp 2.0, competence 1.2 says «critically evaluate the credibility and reliability of sources of data, information and digital content». 
et al. 2016). Here, the authors list a number of projects and initiatives prompted by DigComp. For example, on the basis of the DigComp framework, the Europass CV is going to enable job seekers to evaluate their own digital competence and include the evaluation in their Curricula Vitae. Clearly, these are laudable initiatives - but none of them offers specific details to flesh out the announcement of critical competencies repeatedly mentioned.

\section{UNESCO}

Education is one of the central tenets of the United Nations Educational, Scientific and Cultural Organization (UNESCO). Three years after the foundation of the UNESCO in 1945, the right of everybody to education was expressed in article 26 of the Universal Declaration of Human Rights of the United Nations. This article along with article 19 , which declared freedom of expression and access to information to be a human right, have become guiding principles for the work of UNESCO. The human-rights based approach to education is essential to understand the way UNESCO conceives of literacy. It expresses that education is a human right and as such a universal value. Over many years, UNESCO has launched numerous activities and projects to turn articles 19 and 26 into a reality, and in doing so the UNESCO did not stick to a more traditional understanding of literacy. Early on, different bodies of the UNESCO have had a sense of the challenges posed by the evolving knowledge and information society and the increasing necessity to arrive at a novel concept of literacy. In particular the Grünwald declaration (1982), the Alexandria declaration (2005) and the UNESCO Paris Agenda (2007) articulated the need to intensify activities in this area.

\section{MIL - Media and Information literacy}

By releasing a model Media and Information Literacy Curriculum for Teachers in 2011 (UNESCO 2011), the work of UNESCO proceeded from declarations expressed via long lists of recommendations how to think best of education, as seen, e.g. in the Paris agenda of 2007, to a framework of specific and - in principle - actionable concepts. It seeks to address the educational challenges of digital media and information by making two conceptual decisions that shaped the agenda of the subsequent activities of the UNESCO on education in the digital age: Firstly, it took a unifying approach vis-à-vis traditionally different, but increasingly converging media like radio, television, Internet, newspapers, books, digital archives and libraries. Secondly, it has been designed with teachers in mind as this group is conceived as a gateway for a literate society. Media and Information Literacy (MIL) is conceptualized here for the first time, and since then it has become the flagship of UNESCO's modernized understanding of literacy. 
MIL is an umbrella term that aims at a combination of educational goals typically associated with digital media on the one hand, e.g. understand the role and functions of media in democratic societies, and information literacy on the other, e. g. access information. MIL is not meant to be a competency standard set by UNESCO. Instead, it offers suggestions for institutions, which may decide to set a national standard on MIL competency.

In 2013, UNESCO introduced a global MIL assessment framework. With this incarnation, MIL has reached a level of detail that makes it possible to compare it with its EU counterpart DigComp, the first full-blown version of which was published in the same year. Similar to DigComp, the main goal of MIL assessment framework is to provide evidence-based information for the planning and development of national policies, strategies and competencies on MIL and the implementation of concrete activities aimed at building knowledge societies (UNESCO 2013, 46)

and to facilitate assessment on a country level and on the level of individual citizens or teachers. Accordingly, the MIL assessment framework involves two tiers. Tier one addresses country readiness via macro-statistical indicators, and tier two specifies individual MIL competencies. In what follows, the focus is on tier two, because the concepts offered here relate to the theme of this paper. On tier two, the rationale and associated concepts of MIL assessment is defined. Centrepiece here is the MIL competency matrix, which is composed of the following elements

- MIL components (3)

- MIL subject matters $(3 \times 4)$

- Competencies $(3 \times 4)$

- Levels of proficiency $(3 \times 4)$

- Performance criteria (113)

The elements of the MIL competency matrix form a hierarchical and increasingly specific system that defines MIL competencies. On its highest level are the MIL components access, evaluation and creation. The MIL subject matters are more detailed instances, for each of them is described as a task demand. Competencies are associated with MIL subjects matters and spell out individual or institutional abilities, required to address subject matters successfully. For each of the three components, MIL proposes 4 competencies. For instance, access is a MIL component, one of its subject matters is definition and articulation of a need for information. One of its associated MIL competencies is to determine and to articulate the nature, role and scope of the information and media (content) through a variety of resources. The remaining elements of the matrix (levels of proficiency, performance criteria) specify rules to actually assess the competencies specified via the aforementioned elements of the MIL competency matrix. MIL distinguishes three levels of proficiency (basic, 
intermediate, advanced). For each competency, it offers a number of performance criteria that can be used to actually measure the level of proficiency an individual has achieved.

\section{Comparison of DigComp and MIL}

DigComp and MIL have emerged as two international frameworks of education in the digital age. Both aspire to conceptualize digital literacy and competence, and both EU and UNESCO deploy these conceptualizations as a springboard for policies and initiatives, harnessing the enormous momentum that these organisations have. DigComp and MIL have an elusive dual nature. Each of them is presented as a scientific concept - though with question marks over its underlying methodology, and each of them is the active hub of numerous policies, follow-up projects and activities. This dual nature of DigComp and MIL attests to their importance. With their formative strength, they motivate a critical analysis of themselves. Given that both DigComp and MIL reflect a work in progress, the analysis offered in the following is meant to be constructive. The aim is to inspire further consideration of key aspects that merit further attention.

\section{Methodological Approach}

How many digital literacies, competencies or skills are there? What could be reliable and valid ways to assess them? What are their indicators? What could be a possible methodological approach to investigate effects and also possible side-effects of an implementation of DigComp and MIL? The methodological status of constructs like digital literacy, media literacy is notoriously elusive, and the same applies to the other methodological issues raised above. DigComp and MIL have not created these problems, but inherited them from the discussions predating both frameworks. However, they do little to address them. DigComp is silent about most questions concerning the methodological status and measurement of digital competencies let alone the societal implications of an implementation of DigComp. The authors of MIL, by contrast, provide a methodologically reflective account regarding the first two aspects mentioned. For instance, they discuss why a multiple latent trait model would be suitable for measuring MIL (UNESCO 2013, 77f). It is conceded by the authors that given the boundary conditions under which UNESCO operates, such an approach would be difficult when applied to international comparisons. Still, a psychometric analysis of MIL that will, e.g. involve the administration of item pools is announced for the next development phase (UNESCO 2013, 86). But again they are silent when it comes to possible implications and side-effects within societies that are educated in digital aspects, which in itself is bound to have mediatization effects. 
When it comes to sharpening the meaning of constructs, a possible methodological starting point would be to harness the wisdom of a wide and diverse community over what constructs like media literacy mean, how they change and how they can be assessed. To translate this option into a sound and transparent method is a challenge which in DigComp deserves more attention. In fact, DigComp seems to use the input of a wider community on digital competence. Prior to DigComp 1 (Ferrari 2013) a literature review was conducted, and a Delphi study with experts was carried out (Ferrari 2012; Janssen et al. 2013). The transition from DigComp 1 to DigComp 2 involved a number of feedback activities as reported in (Vuorikari et al. 2016), but the method deployed to use this feedback has not been made explicit.

The initial of development of MIL has also been informed by consulting experts in the field (Lee et al. 2013). UNESCO (2011) mentions various surveys, but their specific contribution to MIL remains unclear. As of February 2017, UNESCO is conducting an expert survey on Media and Information Literacy as part of an ongoing effort to improve MIL ( UNESCO and You: Participate now in Expert Survey on Media and Information Literacy» 2017). Hence, like DigComp, MIL keeps the door open for a participation of an international community of experts.

Despite this openness MIL and even more so DigComp are still very inward-looking and self-referential endeavours. Previous papers or declarations are extensively referenced at the expense of liaising with or referring to the scientific community outside projects funded. It follows that there is bleak prospect of DigComp and MIL adapting to new challenges of digital communication, epitomized by social bots and fake news. Large institutions tend to react mainly to inner discussions, in line with their own agenda. Perhaps a less self-referential stance with regard to their own institutions and a stronger working relationship to the scientific community, could benefit both frameworks. Thus the goal to improve the methodological side of DigComp and MIL could be better achieved.

\section{Atomization as a Heuristic Principle}

Both frameworks rely on an analytic methodology that seeks to atomize literacies and competencies, required to address the multitude of educational challenges in the digital age. Clearly, this approach resembles classical Taylorism, often applied in the workplace when complex activities are broken down into smaller units, in an attempt to increase the overall efficiency and/or to dovetail the work of humans and machines. But this itself is not the main reason to be concerned about. A truly lamentable omission is that reflection - a competence that most educators will want to foster among educatees - does not seem to be applied to the educational frameworks itself. Otherwise, the authors of DigComp and MIL would have given more consideration to the potentials and limits of their approach with regard to the self-set goals 
behind both frameworks. For instance, if critical thinking is a goal of both DigComp and MIL, what remains of it once it is broken down in extremely small entities? Consider critical evaluation (MIL component 2). Now let us break this component down into the MIL subject matters understanding, assessment, evaluation and organisation. In doing so, we strictly followed MIL. However, the meaning of what critical thinking actually means in digital settings does not become more specific, but it seems to have vaporized away. Even though some of the problems related to the use of atomization as heuristic principle have just been illustrated by using an example of MIL, the same issues apply to DigComp as well.

Role of Digital Media in Public Discourse

Digital media have come a long way. The first Personal Computers, the early World Wide Web (Web 1.0), the interactivity that came with Web 2.0, the new generation of Web application, e. g. Al, virtual Reality (Web 3.0) call for different competencies and literacies. The abilities required to work with Personal Computers and basic Web applications are covered by DigComp and MIL. However, the - not exactly new - developments related to Web 2.0 and the competencies and literacies required to address them appropriately, seem to be acknowledged and accounted for only by MIL. The analysis of social media as an incarnation of Web 2.0 is particularly insightful with regard to the ambivalent role it has in public discourse. It is ambivalent as social media are able to facilitate and support a democratic public discourse - but they may also be used for manipulative intentions. It is doubtful whether a framework of digital competence or literacies like DigComp or MIL can live up to its high aspirations if there is no sense for this ambivalence nor even a recognition of the increasing role of digital media for the democratic public discourse. Unfortunately, DigComp is far from an understanding of the role social media play, with regard to public discourse and its role for the stability of democratic societies. MIL, by contrast, comes close to an understanding of this role. This is acknowledged by DigComp in a comparison between DigComp 2.0 and MIL.

$M L$ competencies without direct mapping to DigComp (ML: Understand the role and functions of media in democratic societies; ML: Understand the conditions under which media can fulfil their functions) (Vuorikari et al. 2016, 34)

Clearly, when implementing DigComp a lot is left to initiatives at national or local level, e. g. regarding the emphasis given to a critical attitude of the learners. But it is also true that as of June 2017 even the most recent publications on DigComp do not recognize the place of public discourse in digital media and its role in democratic societies. This is the reason why at the moment it does not seem to be possible to develop consistent strategies, on the basis of the conceptual machinery of DigComp, to address social bots and fake news in educational settings. Any educator 
who is indebted to DigComp and faced with such a situation, will try to improvise and conjure up strategies to fill that conceptual void. But this situation should not occur when working with a framework that aspires to offer a comprehensive coverage of education issues in the digital age. MIL, by contrast, is conceptually far better equipped to address the aforementioned challenges. Still, even in MIL, a better specification of the concepts of public discourse and a contextualisation is required.

\section{Discussion}

Policies matter. Following Suzanne Mettler in her analysis of the political system of the USA (Mettler 2016), one is tempted to apply her pattern of analysis to attempts at setting the agenda for education in the digital age, with the possible outcome of reshaping education in general. Studying DigComp and MIL illustrates that setting the agenda of education in the digital age, takes place in what can be called a policyscape - a landscape in which declarations, reference models and frameworks, programmatic statements and policies have themselves become institutions. They create a new form of governance that is largely unnoticed by the general public and by the scientific community. But it can be expected that that policyscapes associated with DigComp and MIL will translate into government decisions and educational practices that may even change the very idea of education itself. Just because digital media have become an essential part of daily life, the formative power that digital education has, is enormous. This formative power becomes even stronger when agendas for education in the digital age, are defined by influential international organisations like the EU and UNESCO. It is reasonable to expect that the implementation of digital agendas associated with DigComp and MIL, is bound to yield side-effects, in particular mediatization effects, beyond the effects explicitly targeted. Addressing the often-cited digital skill gap with an eye to employability, (being one of the latter), is certainly one of the effects targeted. While western societies react very sensitively, to the implementation to new technologies, they usually remain surprisingly relaxed regarding the implementation of new forms of education - with the remarkable exception of the introduction of comprehensive schools. DigComp and MIL owe their existence to mediatization of the society, and it is reasonable to assume DigComp and MIL in turn contribute to mediatization. The side-effects of initiatives for digital education are difficult to predict, but - somewhat paradoxically - they may in turn lead to an increased mediatization that manifests itself, e. g. by an even stronger reliance on social media and the Internet in daily life. Some of those possible mediatization effects are only discussed in communities outside the DigComp and MIL ecosystems. In order for DigComp and MIL to conceptualize and to roll out frameworks of digital competencies and literacies they have to include and examine the larger frameworks of their work. In short, even digital frameworks have to be what they 
expect educatees to be: Reflective. For DigComp and MIL, this means being reflective about their potentials and limits, about the boundary conditions of their work and able to consider the effects and side-effects they generate.

\section{Literature}

Ala-Mutka, Kirsti, Yves Punie, and Christine Redecker. 2008. «Digital Competence for Lifelong Learning». Luxembourg: Office for Official Publications of the European Communities. http://ftp.jrc.es/EURdoc/JRC48708.TN.pdf.

Ala-Mutka, Kirsti. 2011. «Mapping Digital Competence: Towards a Conceptual Understanding». Luxembourg: Publications Office of the European Union. http://ftp.jrc.es/EURdoc/ JRC67075_TN.pdf.

Bawden, David. 2008. «Origins and Concepts of Digital Literacy». In Digital Literacies: Concepts, Policies and Practices, edited by Colin Lankshear and Michele Knobel, 30:17-32. New York: Peter Lang. http://sites.google.com/site/colinlankshear/DigitalLiteracies.pdf.

Bessi, Alessandro, and Emilio Ferrara. 2016. «Social Bots Distort the 2016 U.S. Presidential Election Online Discussion». First Monday 21 (11). doi:10.5210/fm.v21i11.7090.

Chaffee, Ian. 2016. «Who's to Blame for Fake News and What Can Be Done About It?» USC News Dec 15th. http://news.usc.edu/113738/whos-to-blame-for-fake-news-and-what-can-bedone-about-it/.

Cooke, Nicole A. 2017. «Posttruth, Truthiness, and Alternative Facts: Information Behavior and Critical Information Consumption for a New Age». The Library Quarterly 87 (3): 211-21. doi:10.1086/692298.

Commission of the European Communities. 1995. «White paper on education and training teaching and learning towards the learning society». http://europa.eu/documents/comm/ white_papers/pdf/com95_590_en.pdf.

Connolly, Kate, Angelique Chrisafis, Poppy McPherson, Stephanie Kirchgaessner, Benjamin Haas, Dominic Phillips, Elle Hunt, and Michael Safi. 2016. "Fake news: an insidious trend that ss fast becoming a global problem». The Guardian Dec 2nd. https://www.theguardian. com/media/2016/dec/02/fake-news-facebook-us-election-around-the-world.

Carretero Gomez, Stephanie, Riina Vuorikari, and Yves Punie. 2017. «DigComp 2.1: The Digital Competence Framework for Citizens with Eight Proficiency Levels and Examples of Use». EUR - Scientific and Technical Research Reports. Publications Office of the European Union. JRC106281. doi:10.2760/38842. http://publications.jrc.ec.europa.eu/repository/bitstream/ JRC106281/web-digcomp2.1pdf_(online).pdf.

Dankert, Kevin, and Stephan Dreyer. 2017. «Social Bots - Grenzenloser Einfluss auf den Meinungsbildungsprozess?» Kommunikation und Recht 2: 73-77.

Delvaux, Mady. 2017. «Report with Recommendations to the Commission on Civil Law Rules on Robotics». European Parliament. http://www.europarl.europa.eu/sides/getDoc. do?pubRef=-//EP//NONSGML+REPORT+A8-2017-0005+0+DOC+PDF+V0//EN. 
Eshet-Alkalai, Yoram. 2004. "Digital Literacy: A Conceptual Framework for Survival Skills in the Digital era». Journal of Educational Multimedia and Hypermedia 13 (1): 93-106. https:// www.learntechlib.org/p/4793.

European Committee for Standardization. 2014. European e-Competence Framework 3.0. A common European Framework for ICT Professionals in all Industry Sectors. 16234:2014 (Part 1-4). European Committee for Standardization (CEN), http://www.ecompetences.eu/e-cf3-0-download/.

European Parliament and the Council. 2006. «Recommendation of the European Parliament and the Council of 18 December 2006 on key competencies for lifelong learning». Recommendation 12. Brussels: Official Journal of the European Union. Vol. 30. European Parliament; the Council. http://eur-lex.europa.eu/legal-content/EN/TXT/?uri=celex:32006H0962.

Ferrara, Emilio, Onur Varol, Clayton Davis, Filippo Menczer, and Alessandro Flammini. 2016. «The Rise of Social Bots». Communications of the ACM 59 (7): 96-104. doi:10.1145/2818717.

Ferrari, Anusca. 2012. "Digital Competence in Practice: An Analysis of Frameworks». Report EUR 25351 EN. JRC Scientific; Policy Reports; Publications Office of the European Union Luxembourg. doi:10.2791/82116. http://ftp.jrc.es/EURdoc/JRC68116.pdf.

Ferrari, Anusca, Yves Punie, Barbara N Brečko, and Institute for Prospective Technological Studies. 2013. «DIGCOMP: A Framework for Developing and Understanding Digital Competence in Europe». Luxembourg: Publications Office. doi:10.2788/52966. http://publications.jrc.ec.europa.eu/repository/bitstream/JRC83167/lb-na-26035-enn.pdf.

Gilster, Paul. 1997. Digital Literacy. New York: John Wiley \& Sons, Inc.

Grek, Sotiria. 2016. «Educating Europe: A Story of Shifts and Grand Old Myths». Article No 71. Edinburgh: European Futures. http://www.research.ed.ac.uk/portal/files/23395501/European_Futures_Article_No_71_Grek.pdf.

Ilomäki, Liisa, Sami Paavola, Minna Lakkala, and Anna Kantosalo. 2016. «Digital Competence - an Emergent Boundary Concept for Policy and Educational Research». Education and Information Technologies 21 (3): 655-79. doi:10.1007/s10639-014-9346-4.

Janssen, José, Slavi Stoyanov, Anusca Ferrari, Yves Punie, Kees Pannekeet, and Peter Sloep. 2013. «Experts' Views on Digital Competence: Commonalities and Differences». Computers \& Education 68 (Oktober): 473-81. doi:10.1016/j.compedu.2013.06.008.

Kellner, Douglas, and Jeff Share. 2007a. "Critical Media Literacy, Democracy, and the Reconstruction of Education». In Media literacy: a reader, edited by Donaldo Pereira Macedo and Shirley R. Steinberg, 3-23. New York: Peter Lang. https://cxarchive.gseis.ucla.edu/ xchange/critical-uses-of-media-and-technology/xpress/critical-media-literacy-democracy-and-the-reconstruction-of-education/.

Kellner, Douglas, and Jeff Share. 2007. «Critical Media Literacy: Crucial Policy Choices for a Twenty-First-Century Democracy». Policy Futures in Education 5 (1): 59-69. doi:10.2304/ pfie.2007.5.1.59.

Lanham, Richard A. 1995. «Digital Literacy». Scientific American 273 (3). New York: Munn \& Co.: 198-99. 
Lankshear, Colin, and Michele Knobel, eds. 2008. Digital Literacies. Concepts, Policies and Practices. Vol. 30. New Literacies and Digital Epistemologies. New York, Bern, Berlin, Bruxelles, Frankfurt am Main, Oxford, Wien: Peter Lang. http://sites.google.com/site/colinlankshear/DigitalLiteracies.pdf.

Lee, Alice, Jesús Lau, Toni Carbo, and Natalia Gendina, eds. 2013. Conceptual Relationship of Information Literacy and Media Literacy in Knowledge Societies. Paris: United Nations Educational, Scientific and Cultural Organization (UNESCO). http://www.unesco.org/fileadmin/MULTIMEDIA/HQ/CI/CI/pdf/wsis/WSIS_10_Event/WSIS_-_Series_of_research_papers_-_Conceptual_Relationship_between_Information_Literacy_and_Media_Literacy. pdf.

Iordache Catalina, Baelden Dorien, and Mariën Ilse. 2016. «Reconsidering Digital Skills: A Theoretical Questioning of the Skills That Define e-Inclusion». iMinds-SMIT, Vrije Universiteit Brussel. doi:10.13140/RG.2.1.3229.4007.

Mettler, Suzanne. 2016. «The Policyscape and the Challenges of Contemporary Politics to Policy Maintenance». Perspectives on Politics 14 (02): 369-90. doi:10.1017/S1537592716000074.

Mills, Kathy Ann. 2010. «A Review of the «Digital Turn) in the New Literacy Studies». Review of Educational Research 80 (2): 246-71. doi:10.3102/0034654310364401.

Morris, Meredith Ringel, Scott Counts, Asta Roseway, Aaron Hoff, and Julia Schwarz. 2012. «Tweeting Is Believing?: Understanding Microblog Credibility Perceptions». In Proceedings of the ACM 2012 Conference on Computer Supported Cooperative Work, 441-450. Seattle, Washington: ACM Press. doi:10.1145/2145204.2145274.

Schwarz, Gretchen. 2003. «Renewing the Humanities through Media Literacy». Journal of Curriculum \& Supervision, 19(1): 44-53. http://www.ascd.org/publications/jcs/fall2003/Renewing-the-Humanities-Through-Media-Literacy.aspx.

Seargeant, Philip \& Tagg, Caroline. 2016. «Fake News: The Solution Is Education, Not Regulation». Times Higher Education, Dec 29th, https://www.timeshighereducation.com/blog/ fake-news-solution-education-not-regulation.

Søby, Morten. 2015. «Digital competence - a password to a new interdisciplinary field». Nordic Journal of Digital Literacy 10 (Jubileumsnummer): 4-7. https://www.idunn.no/dk/2015/Jubileumsnummer/digital_competence_-_a_password_to_a_new_interdisciplinary_.

Peter Stordy. 2015. «Taxonomy of literacies». Journal of Documentation 71 (3): 456-76. doi:10.1108/JD-10-2013-0128.

Telecentre Europe. 2014. Digital Competence and Employability. Dec 15th. http://archive.telecentre-europe.org/wp-content/uploads/2015/02/TE_DIGCOMP-policy-paper_FINAL_PDF. pdf.

UNESCO. 2011. «Towards Media and Information Literacy Indicators». UNESCO. http://www. unesco.org/fileadmin/MULTIMEDIA/HQ/Cl/Cl/pdf/unesco_mil_indicators_background_ document_2011_final_en.pdf.

UNESCO. 2013. "Global Media and Information Literacy Assessment Framework: Country Readiness and Competencies». UNESCO. http://unesdoc.unesco.org/ images/0022/002246/224655e.pdf. 
UNESCO. 2017. «UNESCO and You: Participate now in Expert Survey on Media and Information Literacy». UNESCO. http://en.unesco.org/news/unesco-and-you-participate-now-expertsurvey-media-and-information-literacy.

Vuorikari, Riina, Yves Punie, Stephanie Carretero, and Godelieve Van Den Brande. 2016. «DigComp 2.0: The Digital Competence Framework for Citizens. Update Phase 1: the Conceptual Reference Model». JRC Working Paper JRC101254. Joint Research Centre (Seville site). doi:10.2791/11517. http://publications.jrc.ec.europa.eu/repository/bitstream/JRC101254/ jrc101254_digcomp\%202.0\%20the\%20digital\%20competence\%20framework\%20for $\% 20$ citizens.\%20update\%20phase\%201.pdf.

Woolley, Samuel C. 2016. «Automating Power: Social Bot Interference in Global Politics». First Monday 21 (4). doi:10.5210/fm.v21i4.6161. http://firstmonday.org/ojs/index.php/fm/article/view/6161. 